\title{
A Short Synopsis of Srimad Bhagavad Gita in Selected Ten Verses
}

\author{
Nanjundappa S Harshavardhana ${ }^{1 *}$, Kuravanka G Srinivas ${ }^{2}$.
}

${ }^{1} \mathrm{MS}$, FRCS, Dumfries and Galloway Royal Infirmary, Dumfries, United Kingdom.

${ }^{2} \mathrm{MD}$, FRCA, Leicester Royal Infirmary, Leicester, United Kingdom

*Corresponding author contact details: Department of Orthopaedics, A75 Cargenbridge, Dumfries- DG2 8RX, United Kingdom, +44-7711880593; email: nharsha@outlook.com

https://doi.org/10.36018/dsiij.v19i.216

\begin{abstract}
Srimad Bhagavad Gita (SBG) is a very popular spiritual classic of Indian philosophy comprised of 700 verses that form a part of 'Bhishma Parva' in the Mahabharata, the world's longest epic. No commentary and critique of the Mahabharata are considered complete without the emphasis on the SBG and its teachings. Hence, SBG is the 'kernel' that guides mankind by eradicating ignorance and imparting selfknowledge. It is a practical tool that guides one in profound crisis and imparts several self-help tools that are practical even in the contemporary era. The dialogue between Srikrishna and Arjuna explores the origin of creation, nature of the body, soul, mind, and re-incarnation. It recommends one to walk on the path of 'Dharma' (i.e. righteousness duty) performing three key things: i) Righteous Karma (Action); ii) Unswerving Bhakti (Devotion) and iii) Commitment to Jnana (wisdom). The 700 verses are organized into 18 chapters and as three hexads of 6 chapters that guide one to attain 'Moksha' (salvation). The supreme lord also summarizes the key teachings of the Upanishads at relevant places which is a marvel in itself. This short perspective attempts to convey the key message and essence of SBG through a selected ten verses chosen by Sri Swami Dayananda Saraswati (an Advaita Vedantic philosopher) of Arsha Vidya Gurukulam (Anaikatti and Rishikesh, India).
\end{abstract}

Keywords. Srimad Bhagavad Gita, 10 Verses, Mahabharata, Essence, Philosophy, Wisdom

\section{INTRODUCTION}

Srimad Bhavagad Gita (SBG) is a collection of 700 verses that are segregated into 18 chapters and constitutes the 'Nucleus' of the great Indian epic 'Mahabharata'. It is a 'Kernel' that bestows welfare to mankind preparing one to face any situation factually. SBG aims to be the preceptor that liberates the helpless and troubled mind from confusion. Human civilization of all faiths over several millennia has sought refuge in it. It is a very small part hidden in the sixth chapter i.e., the 'Bhishma Parva' in the 'Mahabharata' (a mammoth epic comprised of 18 parvas and over 100,000 verses). The profound philosophy of these verses $(<1 \%$ of the Mahabharata) imparts knowledge and guides one to proceed towards the 'Truth' incorporating the moral, ethical, and 'Dharmic' values for those wishing to walk in this path. It unfolds in the form of a 
conversation/dialogue between two close friends Srikrishna (the supreme lord who had the humility to be a charioteer) and Arjuna (an accomplished warrior and devotee of Srikrishna) wherein Arjuna is struck with grief, sorrow, compassion and loses his nerve to face the enemies imagining the consequences of the war/bloodshed deaths of loved ones. The supreme lord acknowledges Arjuna's conundrum and convincingly answers all his questions, eradicating the ignorance that had clouded his intellect. His preaching in a whopping 574 verses $(82 \%)$ constitutes the bulk of SBG. Arjuna speaks 84 verses (12\%) whilst the remaining $6 \%$ is spoken between the royal narrator Sanjaya (41) and King Dhritarashtra (1). SBG is an outstanding self-help manual and imparts several life lessons. The first and foremost key lesson is the art of Active listening i.e. listening to understand and tackle rather than arguing, wherein the supreme lord doesn't begin his teaching until the $58^{\text {th }}$ verse.

This short monograph is an attempt to summarize the key message and essence of SBG by providing a concise summary through a selection of 10 verses as chosen by Sri Swami Dayananda Saraswati (Anaikatti and Rishikesh, India) (Saraswati 2019) (1). The chosen 10 verses along with chapter-wise citations and their essence are listed as follows (1-2).

\section{CHAPTER 2 VERSE 11}

अशोच्यानन्वशोचस्त्वं प्रज्ञावादांश्र भाषसे।

गतासूनगतासूंश्च नानुशोचन्ति पण्डिताः।।

aśhochyān-anvaśhochas-tvami prajñā-vādānśhcha bhāṣhase gatāsūn-agatāsūnśh-cha nānuśhochanti paṇḍitāḥ

This verse marks the beginning of Srikrishna teachings who is surprised that having previously demonstrated logic and wisdom, how come an accomplished archer is so ignorant at the time of need. He concludes Arjuna is grieving for those who are unworthy of sorrow. He sympathizes acknowledging that death is an inevitable universal event that evokes pain in all and reassures by mentioning that birth and death are the two faces of the same coin. One has to breathe in and breathe out to stay alive and there is no way of knowing when one's last breath would be. Wise people do not grieve over those who are dead or are about to die. He nudges Arjuna to become a 'Viveki' i.e. acquire discriminatory inquisitiveness. He also nudges Arjuna to develop an element of 'Vairagyam' (dispassion to senses, negativity) and stand up to fight as it is Swadharma (duty). The concepts of Pravritti and Nivritti are introduced and he sows the seed for priority to attain 'Moksha' through Swadharma. He further rationalizes suggesting that grieving over someone who has died will not bring them back to life. Alternatively, sorrow is also subjective as the same incident can make one unhappy while the other unaffected. Srikrishna lays the foundation about the nature of 'Atman' as 'Sat-chit-ananda' here.

\section{CHAPTER 2 VERSE 21}

वेदाविनाशिनं नित्यं य एनमजमव्ययम्।

कथं स पुरुषः पार्थ कं घातयति हन्ति कम्।।

vedāvināśhinami nityam̉ ya enam ajam avyayam

katham sa puruṣhaḥ pārtha kam் ghātayati hanti kam

This verse describes the nature of 'Atman'. The 'Self' is eternal, indestructible, and not subjected to change. Neither does it kill nor get killed by anyone. Srikrishna declares that it is neither 'Karta' (doer) nor a 'Bhogta' (i.e., enjoyer) and is not subjected to transformations like birth, growth, decay, death, etc. The body is only an abode that houses the 'Self', while it is ignorance to equate the self with the body. All religions accept that 'Atman' is distinct from the physical body and that it survives after death. An individual who 
understands this has no 'Ahankara' (ego) as his 'Ajnana' is eradicated. It is the removal of this ignorance that paves way for the acquisition of 'Atman jnana' (i.e., self-realization). 'Antaha karana shuddhi' is the first step towards the path of emancipation. The supreme lord recommends one to give up 'Kartatva' (i.e., the notion of doership). An individual with such an attitude isn't affected by the fruit of the action and does what is expected of oneself (swadharma) in a given situation. He preaches Arjuna about 'Sarva karma sanyasa' and recommends him to give up the attitude 'I am the doer' in the action rather than giving up the action.

\section{CHAPTER 2 VERSE 47}

कर्मण्येवाधिकारस्ते मा फलेषु कदाचन।

मा कर्मफलहेतुर्भूर्मा ते सड्गोडस्त्वकर्मणि।।

karmaṇy-evādhikāras te mā phaleșhu kadāchana

mā karma-phala-hetur bhūr mā te san்go 'stvakarmaṇi

This is a very popular verse that professes the notion of 'detachment from the fruits of one's actions. The supreme lord preaches Arjuna that one's choice is only in action and not in its outcomes thereof. He suggests one to develop an attitude of 'karma phala tyaga' and incorporate 'Samatva' (i.e., equanimity) as a part of one's personality. One should graciously accept whatever fruits materialize from actions as a part of divine grace nurturing a notion of 'Prasada Buddhi'. Such an approach gives contentment and peace of mind. An undesirable result doesn't mean one is a failure. An animal act is driven by instincts, unlike humans who have the power of choice. As the consequences of our actions are completely beyond one's control, there is no point in fretting about it. Cultivating this trait gives one the resilience and maturity needed to handle any situation pragmatically (be it at the workplace or in relationships). Such people are mentally and emotionally tougher and do not blame anyone for circumstances. The actions should not be attached with and be driven by the outcome (mā karmaphala-hetur bhūr), rather accepting the outcome as Prasada.

\section{CHAPTER 2 VERSE 55}

प्रजहाति यदा कामान्सर्वान्पार्थ मनोगतान् ।

आत्मन्येवात्मना तुष्टः स्थितप्रज्ञस्तदोच्यते।।

prajahāti yadā kāmān sarvān pārtha mano-gatān

ātmany-evātmanā tușhțaḥ sthita-prajñas tadochyate

This verse is Srikrishna's answer to Arjuna describing the attributes and conduct of a wise person. He mentions that an individual, who gives up all binding desires arising in the mind (sense of doership), needs no other external factor to be happy, and blissful with oneself is known as 'Stithaprajna'. Such an individual reigns on one's senses, mind and develops 'Viveka' (discriminatory inquiry) that state of 'Raga and dveshas' (likes-dislikes). One works on creating conditions that help discover virtues such as loving-kindness, compassion, truth, mutual trust, and understanding. The supreme lord recommends constantly practicing such virtues so that they become one's second nature and spontaneous expression of one's personality. Negative traits (greed, hatred, jealousy, and selfishness) have no place in their personality.

\section{CHAPTER 3 VERSE 3}

लोकेऽस्मिन्द्रिविधा निष्ठा पुरा प्रोक्ता मयानघ।

ज्ञानयोगेन सांख्यानां कर्मयोगेन योगिनाम्।।

loke 'smin dvi-vidhā nișhțhā purā proktā mayānagha

jñāna-yogena sān்khyānāmm karma-yogena yoginām

The supreme Lord answers Arjuna's question when asked which of the two was better to attain emancipation (action vs. wisdom) with this verse. Arjuna is confused because if one can attain liberation merely by knowledge, why commit the 
heinous crime of waging a battle and killing loved ones? Srikrishna clarifies by mentioning that despite sounding easy 'Sanyasa' by renouncing all action is difficult as 'Nishkama karma' (i.e. detached selfless action) is still needed for 'purification of the mind' (i.e. Antaha karana shuddhi) that prepares the mind to be receptive for higher knowledge. He explains the concept of Shreyas (right) vs. Preyas (pleasant). $\mathrm{He}$ rationalizes that the archer was still a 'Karma yogi' and not a 'Sanyasi', given that during the twelve years in forests, all Arjuna ever thought was about Duryodhana's injustice, acquiring weapons, and preparing for the battle. Lord Krishna rationalize to Arjun that his duty is to fight (karma Yoga) with no expectation of outcome (Nishkam karma) which is true Sanyasa (renunciation of outcome). A 'Jnana yogi' pursues only knowledge and has no karma to execute. He has a single-minded devotion to gaining self-knowledge to the exclusion of everything else.

\section{CHAPTER 5 VERSE 6}

संन्यासस्तु महाबाहो दुःखमाप्तुमयोगतः ।

योगयुक्तो मुनिर्ब्रह्म नचिरेणाधिगच्छति।।

sannyāsas tu mahā-bāho duḥkham āptum ayogatạ̣

yoga-yukto munir brahma na chireṇādhigachchhati

Srikrishna emphasizes the importance of 'Karma yoga' in this verse mentioning that 'selfknowledge' is difficult to gain without a degree of proper preparation and that 'Action' prepares one's mind for it. Renunciation of action is easier than doing Karma, and hence the path of 'karma yoga' is necessary before progression towards 'Jnana yoga'. It is like before becoming a surgeon, one has to join medical college and go through a hard process of studies on cadavers. Those harboring likes-dislikes (Raga-dveshas) will have difficulty executing the notion of true 'Sanyasa'. They would only get more frustrated if they take sanyasa prematurely. 'Nyasa' means renunciation a sanyasa means total renunciation with a maturity of mind (balance in likes and dislikes). The supreme lord emphasizes the qualification of being a 'Yoga yukta' whilst being a karma yogi (i.e. one who has mastered over the senses and has purified the mind) to attain the Brahman. No amount of materialistic success and accomplishments provide happiness and contentment to the human soul. It is 'wisdom' alone that is liberating. Karma yoga (Yoga Yukta) is the beginning easier to attain liberation compared to Jnana yoga.

\section{CHAPTER 5 VERSE 13}

सर्वकर्माणि मनसा संन्यस्यास्ते सुखं वशी।

नवद्वारे पुरे देही नैव कुर्वन्न कारयन्।।

sarva-karmāṇi manasā sannyasyā $\bar{a}_{\text {ste }}$ sukham் vaśh $\bar{\imath}$

nava-dvāre pure dehī naiva kurvan na kāarayan

The supreme lord in this verse describes the attributes of an individual who has acquired 'Jnana Nishta' (self-knowledge). The one who realizes 'I' (self) is contented and happy in oneself. The 'self' of such an individual, which is housed in the physical body is compared to a 'nine-gated' city, (comprising of one mouth, two nostrils, two ears, two eyes, and two genital orifices) neither performing any action nor causing others to act. Certain actions are necessary to sustain life even during deep sleep and giving up all actions is practically impossible. No work is a burden for him as he realizes that the self is actionless. He is in supreme control over his body-mind-sense complex and has the 'Viveka' (i.e. discriminatory knowledge) realizing that the 'Self' is distinct from the body. Srikrishna introduces the concept of 'manasa sanyasa' (detachment of the self from body-mind-sense complex). He is reiterating what he preached earlier in chapter 2 that 'Atman' doesn't die or is not subject to destruction. 


\section{CHAPTER 9 VERSE 4}

मया ततमिदं सर्वं जगदव्यक्तमूर्तिना।

मत्स्थानि सर्वभूतानि न चाहं तेष्ववस्थितः।।

mayā tatam idam் sarvam் jagad avyakta-mūrtinā

mat-sthāni sarva-bhūtō̄ni na chāham் teȘhvavasthitaḥ

The supreme Lord mentions that the entire world is pervaded by him and that he is formless, devoid of any attributes, and not objectifiable (Avyakta murthi). Despite all sentient and insentient beings residing in him, he is not based in them. The nature of 'Atman' is 'Sat-chit-ananda' (i.e. existence - consciousness - bliss) that pervades everything and is not limited by time and space. For example - the gold chain needs gold for its identity (namarupa), whilst 'Gold' is independent of the chain (i.e. Swarupa). There is no chain without gold i.e. Gold is Satya and chain is mithya. So is the nature of 'Atman' (i.e. Self), which has no connection to anything. The Atman is not subjected to birth, growth, decay, death, etc. unlike the physical body, and is distinct from the body. Atman is not connected to anything and yet recognizes everything and is non-dual i.e. Chaitanya atman. Srikrishna summarizes that he is the basis (Adhara) for creation but not it's 'Adhyeya' (sub-section).

\section{CHAPTER 18 VERSE 46}

यतः प्रवृत्तिर्भूतानां येन सर्वमिदं ततम्।

स्वकर्मणा तमभ्यर्च्य सिद्धिं विन्दति मानवः।।

yatạ̣ pravṛittir bhūtānām yena sarvam idami tatam

sva-karmaṇā tam abhyarchya siddhim vindati mānavaḥ

The supreme lord recommends one to perform duty with a proper attitude adhering to one's dharma. Such an undertaking is equivalent to worshipping the Lord and dharma and Ishwara are one and the same. Working in such manner brings delight to the soul as there is a sense of humility in one's conduct. An act/work undertaken with appropriate 'Bhavana' and that which is nonbinding (no doership - 'Kartatva') brings about an internal transformation 'Antaha karana shuddhi' that cleanses the mind to be receptive for 'Selfknowledge'. Srikrishna declares that he is allpervasive and omniscient in both sentient plus insentient things and an integral part of all five elements: i) Air; ii) Fire; iii) Water; iv) Space and v) Earth. He is both the 'Nimitta karana' (efficient cause) and 'Upadana karana' (material cause) for the creation of this cosmos, just like a spider who weaves the web, the materials for which are produced in its own glands. It is ignorance that considers jiva to be separate from the atman when the truth is 'Satyam Jnanam Anantam Brahman' The supreme lord is both the 'Sukshma Upadhi' and 'Sthula Upadhi' sustaining the entire creation with only a small portion of his energy.

\section{CHAPTER 18 VERSE 66}

सर्वधर्मान्परित्यज्य मामेकं शरणं व्रज।

अहं त्वा सर्वपापेक्यो मोक्षयिष्यामि मा शचः।।

sarva-dharmān parityajya mām ekam் śharạ̣am் vraja

aham் tvāmi sarva-pāpebhyo mokșhayișhyāmi mā śhucha

This is the last verse of the supreme lord's teaching in the Bhagavad Gita and he once again asks Arjuna not to grieve as Gita after all is about the alleviation of sorrow. He recommends Arjuna to take refuge in him with unswerving devotion coupled with faith and the single-minded quest for knowledge. Srikrishna recommends Arjuna to give up all actions both Dharmic and Adharmic (the notion of doership). The lord is willing to take him under his wings sympathizing he would liberate Arjuna from all bondages of desires (Karma) and sins. He would bestow his favorite disciple with the wisdom that would erase this ignorance and release him from bondage. Neither does Karma (i.e. action) nor Bhakti (i.e. devotion) result in liberation, but it is that of 'Atman Jnana' (i.e. self- 
knowledge) that is the path to 'Moksha'. There exists nothing other than 'Ishwara' and Arjuna is inseparable from 'Ishwara' - 'Tat-Tvam-Asi' (that thou art). This constitutes 'Jnana Nistha and Vritti Jnana' that 'Jiva - Jagat - Ishwara' are all one and the same which is the essence of the Gita.

\section{CONCLUSION}

Gita preaches that the greatest battles are fought in one's own mind for self-refinement. An individual is judged by the secret recess of purpose of his actions and Bhavana (purity of heart). The final arbitrator is the 'self' of a man, 1) who has abandoned the attachment to the fruits of actions; ii) who has tamed his senses and the mind from sensory desires; iii) one who has conquered his (likes and dislikes) 'Raga-dveshas', and iv) who has eliminated materialistic self-interest through devotion for the welfare of the society. There isn't any remedy and solution that don't exist in the Gita that doesn't address any problems of human life. One should strive to live by its teachings of SBG to become Yog-Yukta (established in selfSthitPragya) to liberate (Moksha) from 3 enemies (Desires, Anger and Greed) through Swadharma and paths of Karma (action) Yoga, Bhakti (devotion) Yoga, and Jnana (wisdom) Yoga.
Funding: The author declared no specific grant for this research from any funding body i.e. public, commercial or not-for-profit sectors, etc.

Competing interests: None declared.

Patient consent for publication: Not required.

\section{REFERENCES}

1. Saraswati, D. Vision of the Gita: In ten selected verses. Chennai: Arsha Vidya Research and Publication Trust. 2019 (ISBN: 978-9380049786).

2. Saraswati, D. Bhagavad Gita home study course: Vol 1 9. Chennai: Arsha Vidya Research and Publication Trust. 2015 (ISBN: 978-9380049397). 